\title{
Evaluating the Group Lending Development at the Vietnam Bank for Agriculture and Rural Development: A Case Study in Bac Giang Branch II
}

\author{
Do Quang Giam1, Dao Thi Hoang Anh'1, Vu Ngoc Huyen', Lai \\ Phuong Thao', Dao Huu Bao² \& Do Thi Minh Van ${ }^{3}$ \\ ${ }^{1}$ Institute Faculty of Accounting and Business Management, Vietnam National University \\ of Agriculture \\ ${ }^{2}$ The Vietnam Bank for Agriculture and Rural Development-Bac Giang Branch II \\ ${ }^{3}$ Master student, University of Paris Dauphine \& ESCP Europe
}

\begin{abstract}
Group-based lending is a form of loan provision for individuals and households in rural areas for production and consumption purposes. Proceeding from the imbalance between demand and supply on small-scale capital, and also Government policies on sustainable poverty reduction, the Vietnam Bank for Agriculture and Rural Development (Agribank) has coordinated with its local authorities and socio-political organizations to provide loan services via group lending. The purpose of this paper was to evaluate the status of group lending development of the Agribank-Bac Giang Branch II. The paper used secondary data collected from the branch and primary data gathered from 50 representative customers and 10 credit officers related the group lending of the branch. Data analysis methods consisted of descriptive statistics and comparative analysis, incorporated with the measurements for bank performance and quality. The findings show positive prospects in both the bank and customers for the development of group lending activity and obstacles in the group lending development of the branch. The paper also proposes some solutions for the branch to tackle difficulties and promote the development of group lending in the branch in Bac Giang province.
\end{abstract}

\section{Keywords}

Group lending development, microfinance, microcredit, Agribank, Vietnam

Received: June 1, 2020

Accepted: November 10, 2020

Correspondence to dqgiam@vnua.edu.vn

\section{Introduction}

Microfinance has developed in many countries for decades since it first appeared and succeeded in 1976 in Bangladesh with the purpose of poverty reduction, and since then, has propagated to several 
neighboring countries (Odongo \& Lilian, 2013). Nowadays, it has become a useful tool for reducing poverty, enabling poorer households to build assets, increasing incomes, and decreasing a family's vulnerability to shocks. In Vietnam, microfinance is identified as a credit service that provides low-income households and individuals with small loans without guaranteed assets to help them engage in productive activities or small start-up businesses, contributing to their enhancement of income and living conditions (Vietnamese Government, 2005). The formal system, organized from the central Government to the local levels in Vietnam, consists of the People's Credit Funds, Vietnam Bank for Social Policies, and Agribank. The involvement of commercial banks in microfinance is extremely necessary to extend credit to meet the needs of households (Robin et al., 2002). Although the poor or low-income residents have great demand for financial services such as credit, savings, and insurance, it is very difficult for them to access credit by themselves, especially from formal credit sources, therefore, getting a loan via a lending group becomes a better solution for this problem. Realizing the importance and significance of lending groups, the President of Agribank issued regulations on lending for households and individuals through the group/mobile group in the Agribank system (Agribank, 2016). Accordingly, lending groups were voluntarily established from households and individuals living in the same settlement or unit, managed by the Vietnam Farmer's Union, Vietnam Women's Union, and other sociopolitical organizations. The strength of this model is that Agribank has cooperated with these organizations to effectively provide loans to meet the needs of households and individuals via the lending groups. Through these organizations, the borrowers are guided to plan and manage consumption, investments, and income, as well as to cope with risks.

The Agribank-Bac Giang Branch II was selected for a case study since the branch is one of the biggest commercial banks in Bac Giang province. In general, clients of the branch are small farm households living in rural and mountainous areas in Bac Giang province.
Currently, the branch targets lending for agricultural production and rural development to gain benefits from the lending purposes, while narrowing down lending for nonproductive ones. Additionally, the number of targeted customers of the branch is huge with small loan demands over short periods of time, so the branch has to cover many administrative expenses for lending. The main difficulties of the branch's lending are the large operation area, inconvenient infrastructure, far distances from the bank office to clients, and so on. Meanwhile, the procedures for getting bank loans are complicated, and client management of the credit officers at localities is limited, so the branch does not meet the demand for the loans of clients timely and adequately. To overcome the difficulties, the Agribank-Bac Giang Branch II has carried out a group based lending program. However, the share of outstanding loans via the lending groups in the total as well as the group lending amount per client remain low. Up to now in Vietnam, no published articles have shown the development of group lending in potential provinces for agricultural production. Thus, the purpose of the paper was to evaluate group lending development of the Agribank-Bac Giang Branch II in order to propose solutions to tackle difficulties, foster credit growth, meet loan demands timely, and improve credit quality via group lending at the branch.

\section{Literature Review}

Microfinance has developed in many countries around the world and has contributed significantly to poverty reductions, income increments, and living condition improvements of the poor and people in rural and mountainous areas. According to the Food and Agriculture Organization of the United Nations, microfinance is providing basic financial services to poor and low-income households and their micro-enterprises through several financial tools, i.e., savings, credit, leasing, insurance, and cash transfers (FAO, 2005). Meanwhile, the World Bank (2013) defines microfinance as an economic development approach that benefits low-income women and men. Regarding the forms of microfinance, Ledgerwood (1999) and 
Odongo \& Lilian (2013) indicated that group lending can be divided into two types: (i) the first one is implemented by depositors such as commercial banks and institutions that only accept deposits but do not perform credit functions i.e., mutual savings banks, credit unions, credit cooperatives, or unofficial organizations; and (ii) the second category includes rotating social savings activities, club groups, or financial service associations. De Quidt et al. (2018) considered group lending in the context of commercialization, including forprofit and non-profit lending. The introduction of a group-based lending model was implemented by microfinance institutions as a solution to reducing the risk of low-value personal loans (Armendariz \& Morduch, 2007). For more detail, Godquin (2004) and Madajewicz (2011) argue that group lending helps minimize risks because people in the same loan group are linked by mutual responsibility, and if one of them fails to comply with the loan terms such as converting investment objects (for instance, from safe subjects to higher risk subjects), then other members of the group will have a higher probability of being exposed to risks. Therefore, this gives members the motivation to monitor each other. In another study, Dellien et al. (2005) showed that to conduct lending through microfinance institutions, it was necessary to invest time and effort in building social networks for reliable member selection. According to the criteria of each lending group, the lender's role was to provide information about the structure of the loan group, provide training on the loan process, and support administrative procedures for the loan group. Savita (2007) and Maria (2009) argued that group lending would incur additional costs for group formation, training, monitoring, and supervision that may be ineffective as social relationships are lax.

Ahlin \& Suandi (2019) debated that group lending was widely used in countries, lowerincome areas, and low-growth economies. As such, this model is suitable for lending environments. Also in this study, Grameen Bank, one of the two pioneers of microfinance, moved from the group lending model to individual loans after having better financial conditions and more experiences. While group lending forces borrowers to interact with one another, there is a shared responsibility, so the benefits of group lending increase over individual lending. Ghatak (2000) theorized that if borrowers differ in unobserved risk, evaluating group-based general liability contracts would be riskier than individual contracts, provided that lenders have to match borrowers of similar risk to the same group. But when a borrower has borrowed for a sufficient period from a lender, leading to more thorough observations and conclusions about loan risk, the benefits of group lending diminish. Therefore, the study also showed that group lending was valuable to newly established microfinance institutions or microfinance institutions seeking to attract new customers or expand to different environments. From the perspective of the lender, research has shown that the real-world lending model is useful in limiting the lack of information on some segments of the population and reducing the shortage of social capital.

In Vietnam, as well as other developing countries, the role of access to credit for individuals shows the capability of encouraging production through supplying input materials, enhancing living standards, and being the crucial mechanism for overcoming income shocks. Globalization has brought Vietnam many opportunities, but it has caused many challenges for Vietnamese people, especially those who live in remote areas. Therefore, micro-credit development is an objective requirement to ensure thorough growth and to provide all clients in society access to financial services. However, when the proportion of individuals using formal credit was low (about 18.4\%), the reasons were limitations of income and geography (Khanh et al., 2018). To remove these barriers, Agribank has regulated group lending for households and individuals towards increasing loans and expanding clients (Agribank, 2016). Besides this, Nguyen Tho Quang Anh \& Tran Dinh Thao (2017) state that community-based microfinance is considered a feasible mechanism to provide financial services in remote areas in Vietnam, and the lending method of village savings has been shown to be a suitable mechanism for poor 
households to access small loans. In order to target the goal of poverty reduction and implement the new rural development program, the members of the lending group are allowed to join in training courses on production techniques, and agriculture, forestry, and fishery extensions; they have also serviced input materials and product consumption, etc. As reported by Agribank, the number of lending groups in the whole country in 2018 reached 53,481, an increase of $2.1 \%$ as compared to that of 2017 . Total loans provided via lending groups reached 102,125 billion VND in 2018, an increase of $12.46 \%$ as compared to 2017 , while the bad debt ratio was low and slightly increased from $0.31 \%$ in 2017 to $0.33 \%$ in 2018 (Agribank, 2019). These results show a positive performance in the lending groups of the Agribank system; however, Agribank needs to control and reduce the bad debt.

\section{Data and Methods}

\section{Conceptual framework}

In our study, we applied a multi-dimension approach for evaluations on the group lending development at the Agribank-Bac Giang Branch II in Bac Giang province such as width-depth and timeline-space of its loan products, based on quality criteria for loan performance measurements and loan service quality, and criteria for developments in loan quantity (Figure 1).

\section{Data collection}

In order to evaluate the performance of group lending activities, this research used both secondary and primary data. The secondary data were obtained from the published financial statements and performance reports of the Agribank-Bac Giang Branch II to analyze and evaluate the development aspects of group lending on the width, depth and timeline from 2016 to 2018. The primary data were collected from 50 representative customers of the groups and 10 credit officers of the branch who closely work with the lending groups about their evaluations on service quality of the lending group, using 5-point Likert scale structured questionnaires.

\section{Data analysis}

In the research, we employed descriptive statistics and comparative analysis methods incorporated with measurements for bank performance and quality, i.e. growth of total outstanding loans, share of total outstanding loans, bad debt ratio, and group lending activities, to clarify the situation, and evaluate the performance and service quality of the group lending activities. Using the measurements of bank performance via quantitative ratios has been used frequently in reality (Mabwe \& Robert, 2010).

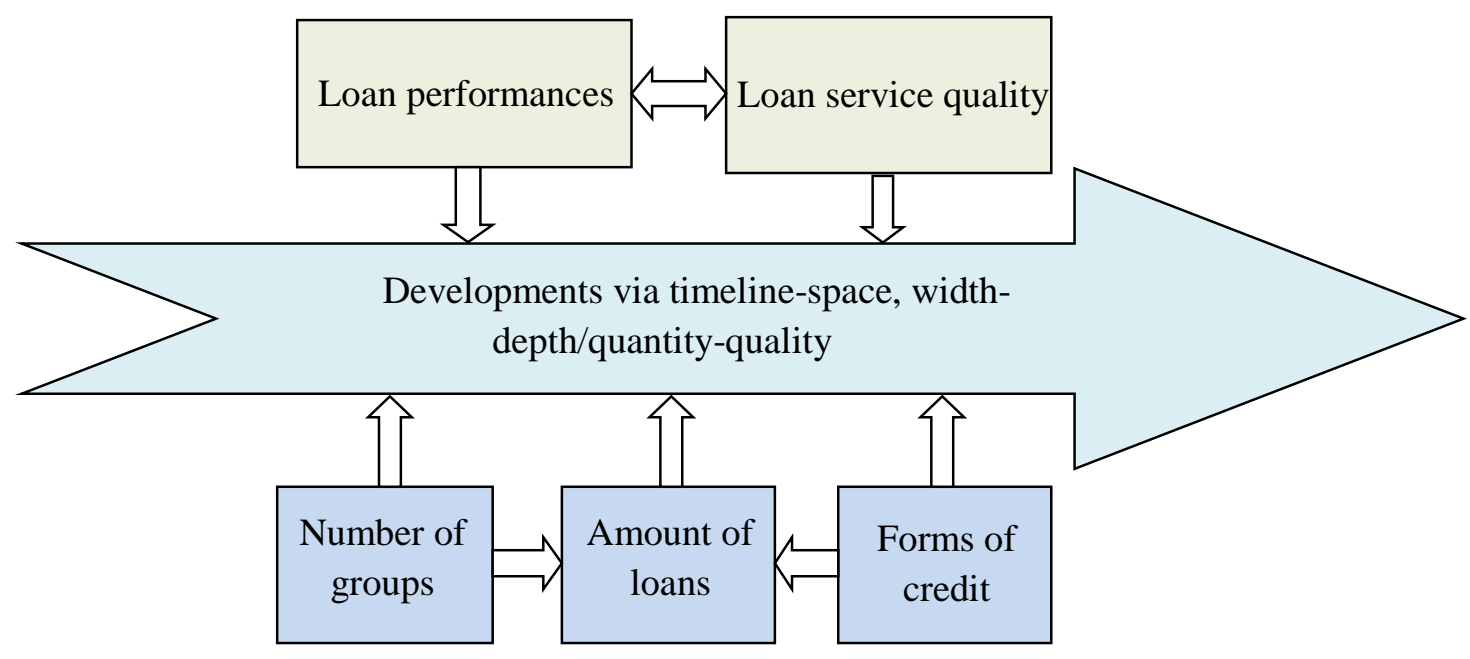

Figure 1. Dimensions for group lending development evaluation at the bank 


\section{Results and Discussion}

In this section, we provide evaluations on the group lending development of the Agribank - Bac Giang Branch II in Bac Giang province in the period of 2016-2018 in different dimensions of development such as timeline-space, quantityquality, and width-depth of its loan products.

\section{Evaluating the group lending development of Agribank- Bac Giang Branch II}

On the growth in the number of lending groups

With the implementation of the interdisciplinary agreement between Agribank and the Vietnam Farmer's Union and the Vietnam Women's Union, while enlisting the support of the local government at various levels, the number of lending groups at the AgribankBac Giang Branch II tended to increase during the period of 2016-2018 with an average growth rate of $4.53 \%$ (Table 1). Encouraging households and individuals to join the lending groups not only brought them economic benefits, but also contributed to the reduction of the number of direct transactions and work pressure of the branch officers, and improved the productivity and quality of customer services.

On the structure and growth of loan formalities via group lending

As indicated in Table 1, in 2016, although the majority of the lending groups of the branch were managed by the Farmer's Union, 555 out of 722 , equivalent to $76.87 \%$ of the total number of groups, the proportion of its outstanding loans in the total was not much different from the lending groups managed by the Women's Union (Table 2), however, the differences were expended in 2017 and 2018. The value of the outstanding loans showed rapid growth in all the districts in the period of 2016-2018, except in the urban zone of Bac Giang city where slow growth was observed. The main purpose of lending was for agricultural production and business activities, accounting for $79.98 \%, 75.00 \%$, and $72.00 \%$ of the total group lending in 2016, 2017, and 2018, respectively. The loan demands for short- or medium-term and long-term loans tended to increase over the 3-year period.

It can be seen that the appearance of group lending helped individuals and households access credit that they were not eligible to borrow formerly. In addition, according to Decree No. 55/2015/ND-CP and Decree No. 116/2018/ND$\mathrm{CP}$ on amending some articles of Decree No. $55 / 2015 / \mathrm{ND}-\mathrm{CP}$ about the credit policies in agriculture and rural development, it is not necessary to have collateral when borrowing if the size of the loans is within the permitted limits (Vietnamese Government, 2015). From the bank's point of view, deploying formal loans through group lending has captured the credit demands for the production, businesses, and consumption of borrowers in a timely manner, thereby preventing borrowers from seeking out black market credit since the majority of loans provided for clients via groups were without collateral, about $90 \%$ in average in the period of 2016-2018 (Table 2).

Table 1. Number of lending groups of the branch in 2016-2018

\begin{tabular}{|c|c|c|c|c|c|c|c|c|}
\hline \multirow{2}{*}{ Norm } & \multicolumn{2}{|c|}{2016} & \multicolumn{2}{|c|}{2017} & \multicolumn{2}{|c|}{2018} & \multicolumn{2}{|c|}{ Diff. (\%) } \\
\hline & \#groups & $\%$ & \#groups & $\%$ & \#groups & $\%$ & $2017 / 16$ & $2018 / 17$ \\
\hline $\begin{array}{l}\text { Total lending } \\
\text { groups }\end{array}$ & 722 & 100 & 755 & 100 & 789 & 100 & 4.57 & 4.50 \\
\hline $\begin{array}{l}\text { Managed by } \\
\text { Farmer's } \\
\text { Union }\end{array}$ & 555 & 76.87 & 589 & 78.01 & 621 & 78.71 & 6.13 & 5.43 \\
\hline $\begin{array}{l}\text { Managed by } \\
\text { Women's } \\
\text { Union }\end{array}$ & 145 & 20.08 & 146 & 19.34 & 153 & 19.39 & 0.69 & 4.79 \\
\hline $\begin{array}{l}\text { Managed by } \\
\text { other } \\
\text { organizations }\end{array}$ & 22 & 3.05 & 20 & 2.65 & 15 & 1.90 & -9.09 & -25.00 \\
\hline
\end{tabular}

Source: Agribank-Bac Giang Branch II (2019) 
Table 2. Loan structures and growths via group lending in 2016-2018

\begin{tabular}{|c|c|c|c|c|c|c|c|c|}
\hline \multirow[b]{2}{*}{ Norm } & \multicolumn{2}{|c|}{2016} & \multicolumn{2}{|c|}{2017} & \multicolumn{2}{|c|}{2018} & \multicolumn{2}{|c|}{ Diff. (\%) } \\
\hline & $\begin{array}{l}\text { Value } \\
\text { (mil. } \\
\text { VND) }\end{array}$ & $\%$ & $\begin{array}{l}\text { Value } \\
\text { (mil. } \\
\text { VND) }\end{array}$ & $\%$ & $\begin{array}{l}\text { Value } \\
\text { (mil. } \\
\text { VND) }\end{array}$ & $\%$ & $2017 / 16$ & $2018 / 17$ \\
\hline Total outstanding loans & 750,665 & 100 & 930,238 & 100 & $1,226,545$ & 100 & 23.92 & 31.85 \\
\hline \multicolumn{9}{|l|}{ 1. Classified by deposit funds } \\
\hline Via Farmer's Union & 417,575 & 55.63 & 590,630 & 63.49 & 777,492 & 63.39 & 41.44 & 31.64 \\
\hline Via Women's Union & 317,825 & 42.34 & 326,556 & 35.10 & 438,850 & 35.78 & 2.75 & 34.39 \\
\hline Via other organizations & 15,265 & 2.03 & 13,052 & 1.40 & 10,203 & 0.83 & -14.50 & -21.83 \\
\hline \multicolumn{9}{|l|}{ 2. Classified by districts } \\
\hline Headquarter & 25,688 & 3.42 & 26,888 & 2.89 & 28,665 & 2.34 & 4.67 & 6.61 \\
\hline Luc Ngan & 135,998 & 18.12 & 199,462 & 21.44 & 235,998 & 19.24 & 46.67 & 18.32 \\
\hline Lang Giang & 110,555 & 14.73 & 155,666 & 16.73 & 196,892 & 16.05 & 40.80 & 26.48 \\
\hline Yen The & 88,688 & 11.81 & 103,442 & 11.12 & 166,882 & 13.61 & 16.64 & 61.33 \\
\hline Son Dong & 85,163 & 11.35 & 98,223 & 10.56 & 155,222 & 12.66 & 15.34 & 58.03 \\
\hline Luc Nam & 191,707 & 25.54 & 202,336 & 21.75 & 255,663 & 20.84 & 5.54 & 26.36 \\
\hline Bac Giang City & 43,868 & 5.84 & 45,665 & 4.91 & 48,665 & 3.97 & 4.10 & 6.57 \\
\hline Bo $\mathrm{Ha}$ & 68,998 & 9.19 & 98,556 & 10.59 & 138,558 & 11.30 & 42.84 & 40.59 \\
\hline \multicolumn{9}{|l|}{ 3. Classified by purposes } \\
\hline For agricultural, production, and business & 600,352 & 79.98 & 697,678 & 75.00 & 883,112 & 72.00 & 16.21 & 26.58 \\
\hline For consumption & 150,313 & 20.02 & 232,560 & 25.00 & 343,433 & 28.00 & 54.72 & 47.68 \\
\hline \multicolumn{9}{|l|}{ 4. Classified by forms of guarantee } \\
\hline Without collateral & 701,356 & 93.43 & 837,556 & 90.04 & $1,021,338$ & 83.27 & 19.42 & 21.94 \\
\hline With collateral & 49,303 & 6.57 & 92,682 & 9.96 & 205,207 & 16.73 & 87.98 & 121.41 \\
\hline \multicolumn{9}{|l|}{ 5. Classified by loan terms } \\
\hline Short and medium terms & 287,505 & 38.30 & 384,188 & 41.30 & 570,343 & 46.50 & 33.63 & 48.45 \\
\hline Long-term & 463,160 & 61.70 & 546,050 & 58.70 & 656,202 & 53.50 & 17.9 & 20.17 \\
\hline
\end{tabular}

Source: Agribank-Bac Giang Branch II (2019).

\section{Evaluating the performance of group lending development of Agribank- Bac Giang Branch II}

Table 3 shows that the ratio of total outstanding loans to total deposited amounts at the Agribank-Bac Giang Branch II increased over 3 years (2016-2018), and reached $81.29 \%$ in 2018, which is a little bit lower in comparison to the average of the Agribank system in 2018 (84.84\%) (Agribank, 2019). For the group lending activities, although it accounted for a small proportion of the total outstanding loans, there was an increasing trend over 3 years (from $11.3 \%$ in 2016 to $13.4 \%$ in 2018 ). The growth rate of outstanding loans through group lending was remarkable $(23.92 \%$ and $31.85 \%$ in the period of 2016-2018), showing that the group lending activities attracted the participation of individuals and households. The average loan size per member of the groups was about 40-60 million VND over the period, within the permitted limits from the confirmed information of loans without collaterals (the highest limit was 100 million VND). The bad debt ratios of the group lending at the branch were small and had a decreasing trend over the period, especially in 2018 when it was only $0.17 \%$, lower than that of the direct lending method (0.53\%) (Agribank, 2019).

\section{Evaluating the service quality of the group lending}

In this section, we use primary data collected from 50 representative customers and 10 credit 
Table 3. The performances of group lending at the branch in 2016-2018

\begin{tabular}{|c|c|c|c|c|c|}
\hline No. & Norm & Unit & 2016 & 2017 & 2018 \\
\hline 1 & Total deposits & mil. VND & $8,466,000$ & $9,816,000$ & $11,308,000$ \\
\hline 2 & Total outstanding loans & mil. VND & $6,635,000$ & $7,807,000$ & $9,192,000$ \\
\hline 3 & Outstanding loans of the group lending & mil. VND & 750,665 & 930,238 & $1,226,545$ \\
\hline 4 & Number of members & persons & 18,050 & 20,630 & 22,491 \\
\hline 5 & Bad debt of the group lending & mil. VND & 1,880 & 2,050 & 2,080 \\
\hline 6 & Growth of loans via the group lending & $\%$ & - & 23.92 & 31.85 \\
\hline 7 & Total outstanding loans/Total deposit= (2)/(1) & $\%$ & 78.37 & 79.53 & 81.29 \\
\hline 8 & $\begin{array}{l}\text { Outstanding loans of the group lending/ Total } \\
\text { outstanding loans }=(3) /(2)\end{array}$ & $\%$ & 11.314 & 11.915 & 13.344 \\
\hline 9 & Average outstanding loans/Member $=(3) /(4)$ & mil. VND & 41.59 & 45.09 & 54.53 \\
\hline 10 & Bad debt ratio of group lending $=(5) /(3)$ & $\%$ & 0.25 & 0.22 & 0.17 \\
\hline
\end{tabular}

Source: Agribank-Bac Giang Branch II (2019)

Table 4. Cronbach's Alpha Test

\begin{tabular}{lc}
\hline \multicolumn{1}{c}{ Factors } & Cronbach's Alpha \\
\hline 1. For credit officers & \\
- Loan process and services quality & 0.8523 \\
- Information technology & 0.8073 \\
2. For representative customers & \\
- Quality of the group lending product & 0.7155 \\
\hline
\end{tabular}

officers as mentioned above to evaluate the service quality of the group lending according to the following criteria:

For the 10 credit officers: (i) Loan process and services quality with 4 observed variables; (ii) Information technology with 2 observed variables;

For the 50 representative borrowers of the groups: Quality of the group lending product with 6 observed variables.

Calculation results of Cronbach's Alpha coefficients in Table 4 show that Cronbach's Alpha is satisfactory $(>0.6)$ and the observed variables have a total correlation coefficient of over 0.3. Therefore, it can be concluded that the variables used in this study are appropriate and reliable (Nunnally \& Bernstein, 1994).

\section{Evaluations from the credit officers engaging in the group lending}

The credit officers assessed that it was not so convenient and simple to complete a loan application due to the large number of documents and stages. Therefore, in order to shorten the process and improve the service quality, most of the bank staff participated in short-term training courses on these issues organized at the Agribank-Bac Giang Branch II. However, the most important issue limiting the enthusiasm at work is that the remuneration policy is not appreciated by the credit officers. Besides, operation on the IPCAS system is sometimes very slow due to unstable internet connection quality, so this reduces the performance of the credit officers (Table 5).

\section{Evaluations from the customers of the group lending}

Under the implementation of group lending, access to bank loans for individuals and households has increased. Table 6 indicates that although the credit officers serve devotedly, customers of the group lending still believe that the loan process and procedures are quite complicated. It takes time for filling out and appraising applications to complete all the 
Table 5. Evaluation of the credit officers for the group lending quality

\begin{tabular}{|c|c|c|c|c|c|c|}
\hline \multirow[b]{2}{*}{ Criterion } & \multicolumn{5}{|c|}{ Scale (\%) } & \multirow[b]{2}{*}{ Mean } \\
\hline & $\begin{array}{c}\text { Strongly } \\
\text { disagree (1) }\end{array}$ & $\begin{array}{l}\text { Disagree } \\
\text { (2) }\end{array}$ & $\begin{array}{l}\text { Neutral } \\
(3)\end{array}$ & $\begin{array}{l}\text { Agree } \\
(4)\end{array}$ & $\begin{array}{l}\text { Strongly } \\
\text { agree (5) }\end{array}$ & \\
\hline \multicolumn{7}{|l|}{ 1. Loan process and services quality } \\
\hline - Loan application is simple and fast & 0.0 & 30.0 & 40.0 & 20.0 & 10.0 & 3.1 \\
\hline - Loan procedure is quick & 0.0 & 10.0 & 50.0 & 20.0 & 20.0 & 3.5 \\
\hline $\begin{array}{l}\text { - Credit officers are trained with improved } \\
\text { qualifications }\end{array}$ & 0.0 & 0.0 & 30.0 & 60.0 & 10.0 & 3.8 \\
\hline $\begin{array}{l}\text { - Remuneration policy encourages credit } \\
\text { officers }\end{array}$ & 0.0 & 0.0 & 70.0 & 20.0 & 10.0 & 3.4 \\
\hline \multicolumn{7}{|l|}{ 2. Information technology } \\
\hline $\begin{array}{l}\text { - IPCAS system can satisfy management } \\
\text { requirements }\end{array}$ & 0.0 & 0.0 & 70.0 & 30.0 & 0.0 & 3.3 \\
\hline - Internet quality is very good & 0.0 & 50.0 & 40.0 & 10.0 & 0.0 & 2.6 \\
\hline \multicolumn{7}{|l|}{ Source: Surveyed data (2019) } \\
\hline \multirow[b]{2}{*}{ Criterion } & \multicolumn{5}{|c|}{ Scale (\%) } & \multirow[b]{2}{*}{ Mean } \\
\hline & $\begin{array}{c}\text { Strong } \\
\text { disagree (1) }\end{array}$ & $\begin{array}{l}\text { Disagree } \\
\quad(2)\end{array}$ & $\begin{array}{l}\text { Neutral } \\
(3)\end{array}$ & $\begin{array}{l}\text { Agree } \\
(4)\end{array}$ & $\begin{array}{c}\text { Strong } \\
\text { agree (5) }\end{array}$ & \\
\hline - Loan process is simple & 0.0 & 26.0 & 50.0 & 20.0 & 4.0 & 3.0 \\
\hline $\begin{array}{l}\text { - Service attitude is whole-hearted and } \\
\text { thoughtful }\end{array}$ & 0.0 & 0.0 & 16.0 & 40.0 & 44.0 & 4.3 \\
\hline $\begin{array}{l}\text { - Levels of the loans and interest of the group } \\
\text { lending is reasonable }\end{array}$ & 0.0 & 16.0 & 56.0 & 24.0 & 4.0 & 3.2 \\
\hline $\begin{array}{l}\text { - Level of commission for the group leader is } \\
\text { reasonable }\end{array}$ & 0.0 & 32.0 & 44.0 & 24.0 & 0.0 & 2.9 \\
\hline $\begin{array}{l}\text { - Number of members in each lending group is } \\
\text { reasonable }\end{array}$ & 0.0 & 16.0 & 44.0 & 40.0 & 0.0 & 3.2 \\
\hline $\begin{array}{l}\text { - Utilities and services accompanying the loan } \\
\text { packages are reasonable }\end{array}$ & 0.0 & 46.0 & 54.0 & 0.0 & 0.0 & 2.5 \\
\hline
\end{tabular}

Source: Surveyed data (2019)

the procedures. While the levels of the loans and interest of the group lending are considered to be quite reasonable for small farms, some big farm households want to expand the loan sizes since each member of the group basically borrows within the permitted limits without collateral. The commission paid to the group leader has not yet been associated with the credit quality criteria, and the commission level is not attractive to encourage the group leader to present their responsibility to monitoring the activities of the group. Customers also reported that the number of group members is really appropriate. However, the products and services of the group lending associated with the loan packages are limited or not available, i.e., technology transfer or agricultural technique guides, so the agricultural activities of individuals and households are still based on their experiences, and this can easily lead to increased credit risk and decreased credit service quality.

\section{Conclusions}

With the focus on expanding the formal credit activities according to the government policies, development of group lending at Agribank-Bac Giang Branch II has achieved certain results. The credit balance has been 
expanded while the proportion of outstanding loans via group lending has increased in recent years. This reduces the workload of credit officers. In addition, the bad debt ratios of the group lending are controlled at low levels and have a downtrend over the years, which contribute to the reduction of the overall bad debts ratio of the branch and consequently increase the credit quality. However, through the evaluations of customers and credit officers of the group lending, some obstacles limit development of group lending such as the complexity of loan documents, lack of customer information management, unspecified regulations in the loan packages, and ineffective attraction to customers of the group lending.

In order to strengthen the group lending development for the branch in Bac Giang province, some crucial policy implications should be considered by the government and president of Agribank such as (i) Building flexible lending mechanisms by improving loan processes and procedures; diversifying lending methods; increasing the level of loans without collateral or considering the form of security with future properties to create favorable conditions for borrowers in accessing bank loans; (ii) Consolidating and perfecting the network of customer information collection and processing for common use of the bank in order to reduce the time for loan processing; (iii) Improving the capability of credit officers in particular and bank officers in general based on the criteria of recruiting new employees, and requiring staff to participate in professional training courses; (iv) Strengthening the implementation and coordination between banks, local authorities, and social associations through seminars, and improving the responsibilities of the parties to achieve common benefits; and (v) Introducing mechanisms on commission levels to the group leaders by linking the payments to certain performances in order to create pressure for them as well as leverage that stimulates the development of the group lending, e.g., reducing overdue debts, bad debts, and actual interest rates.

\section{References}

Agribank (2016). Decision No. 5199/QD-NHNo-HSX issued on December 30, 2016 on the lending regulations for households and individuals via lending groups, linkage groups, mobile lending groups applied in the Agribank system (in Vietnamese).

Agribank (2019). Annual report of Agribank 2018 (in Vietnamese).

Agribank-Bac Giang Branch II (2019). Annual reports (2016, 2017, 2018) of the Agribank- Bac Giang Branch II (in Vietnamese).

Ahlin C. \& Suandi M. (2019). A master of experience? Understanding the decline in group lending. Oxford Bulletin of Economics and Statistics. 81(6): 12521279. DOI: 10.1111/obes.12305.

Armendariz B. \& Morduch J. (2007). The Economics of Microfinance. MIT Press, Cambridge, MA.

Dellien H., Burnett J., Gincherman A. \& Lynch E. (2005). Product diversification in microfinance: Introducing individual lending. Women's World Banking Report, New York: 1-36.

De Quidt J., Fetzer T. \& Ghatak M. (2018). Commercialization and the decline of joint liability microcredit. Journal of Development Economics. 117: 119-133.

FAO (2005). FAO Forestry Paper 146: Microfinance and forest-based small-scale enterprises. Food and Agriculture Organization of the United Nations, Rome, ISBN 92-5-105412-6, 88p.

Ghatak M. (2000). Screening by the company you keep: Joint liability lending and the peer selection effect. Economic Journal. 110(465): 601-631.

Godquin M. (2004). Microfinance repayment performance in Bangladesh: How to improve the allocation of loans by MFIs. World Development. 32: 1909-1926.

Hoang Cong Gia Khanh, Nguyen Thi Canh, Le Ho An Chau, Nguyen Thanh Liem, Hoang Trung Nghia, Dao Thi Ngoc, Nguyen Ton Nhan, Nguyen Anh Phong, Nguyen Thi Dan Que, Pham Phu Quoc, Tran Hung Son, Nguyen Hong Thang, Nguyen Dinh Thien, Tran Quang Van \& Pham Thi Thanh Xuan (2018). Annual report 2017 on financial market: Access to finance. Ho Chi Minh City National University Publishing House, 162p (in Vietnamese).

Ledgerwood J. (1999). Microfinance Handbook: An Institutional and Financial Perspective (Sustainable Banking with the poor). The World Bank, Washington, D.C., ISBN 0-8213-4306-8, 262p.

Mabwe K. \& Robert W. (2010). A financial ratio analysis of commercial bank performance in South Africa. African Review of Economics and Finance. 2(1): 30-53.

Madajewicz M. (2011). Joint liability versus individual liability in credit contracts. Journal of Economic Behavior and Organization. 77: 107-123.

Maria L. (2009). Group lending versus individual lending in microfinance. Discussion paper No. 299. University of Munich.

Nguyen Tho Anh \& Tran Dinh Thao (2017). Evaluating the impact of village savings and loans model on living 
conditions of rural women: A case study in Quang Binh and Quang Tri province. Vietnam Journal of Agricultural Sciences. 15(9): 1309-1321 (in Vietnamese).

Nunnally J. C. \& Bernstein I. H. (1994). The assessment of reliability. Psychometric Theory. 3: 248-292.

Odongo K. \& Lilian G. K. (2013). Individual lending versus group lending: An evaluation with Kenya's microfinance data. Review of Development Finance. 3: 99-108.

Robin B., Annie H. \& Dyson M. (2002). Can commercial banks do microfinance? Lessons from the Commercial Bank of Zimbabwe and Co-operative Bank of Kenya. Small Enterprise Development Journal. 13(4): 35-46.
Savita S. (2007). Transaction costs in group microcredit in India. Management Decisions. 45: 1331-1342.

Vietnamese Government (2005). The Decree No.28/2005/ND-CP, issued on March 9, 2005 on organization and operation of microfinance institutions in Vietnam (in Vietnamese).

Vietnamese Government (2015). Decree No. 55/2015/NDCP and Decree No.116/2018/ND-CP on amending some articles of Decree No. 55/2015/ND-CP on credit policy in agriculture and rural development (in Vietnamese).

World Bank (2013). CGAP Annual report 2013: Advancing financial inclusion to improve the lives of the poor (English). The World Bank, Washington, D.C., 52p. 